\title{
ANALISIS PENGARUH RASIO KEUANGAN TERHADAP RETURN ON ASSET BANK PERKREDITAN RAKYAT PADA PT. BPR POLIN JAYA
}

\author{
Dedi Mulyadi \\ Universitas Buana Perjuangan Karawang \\ Alexander Din \\ Universitas Singaperbangsa Karawang
}

Dedimulyadi@ubpkarawang.ac.id , alexanderdin76@gmail.com

\begin{abstract}
Influence Analysis of Financial Ratios Return on Assets Rural Bank in PT . BPR Polin Jaya.

The purpose of this study was to obtain empirical evidence and find clarity phenomena and conclusions about the effect of variable Financial Ratios Return on Assets Rural Bank in PT. BPR Polin Jaya

This thesis is expected to provide input for the bank and customer management for decision making with regard to CAR, NPL, NIM, ROA, LDR and ROA, and economics in general.

This research uses descriptive and verification methods, namely; collecting, presenting, analyzing, and testing hypotheses, and make conclusions and suggestions.

From the analysis of research data, obtained the following conclusions:

1. The role of capital adequacy of banks in running the business anyway, is something that absolutely must be met. With the fulfillment of CAR by the bank then the bank can absorb losses suffered, so that the activities carried out will be run efficiently, and ultimately the profits from the bank is increasing.

2. The role of the bank's management is very cautious in lending to borrowers so as to minimize loans become problematic

3. The ability of banks to earn interest income from the good and bad effect on the bank's Return on Assets. If the acquisition of the bank NIM ratio increases, the Return on Assets (ROA) of the bank will also increase.

4. The level of efficiency of the bank's operating costs greatly affect the Return on Assets. The more efficient or small bank operating costs, the profit gained greater

5. The level of liquidity of a bank affects the bank's Return on Assets. The more optimal level of liquidity the bank, then the third party funds disbursed in the form of greater credit. With the growing amount of credit granted, the profits to be gained are also getting bigger

6. Effect of CAR, NPL, NIM, ROA, LDR simultaneously significant effect on ROA of $92.7 \%$
\end{abstract}

14.

Jurnal Manajemen \& Bisnis Kreatif 
From these results, it can be concluded that the Return on Assets can be influenced by CAR, NPL, NIM, ROA, LDR, which means Return on Assets can be enhanced through improved CAR, NPL, NIM, ROA, LDR accordance with the regulations of Bank Indonesia and Otoritas Jasa Keuangan.

Keywords: CAR, NPL, NIM, BOPO, LDR dan ROA

\section{BAB I}

\section{PENDAHULUAN}

\subsection{Latar Belakang Penelitian}

Berdasarkan Undang Undang Nomor 10 Tahun 1998 tentang Perbankan, Perbankan adalah segala sesuatu yang menyangkut tentang bank, mencakup kelembagaan, kegiatan usaha, serta cara dan proses dalam melaksanakan kegiatan usahanya sedangkan bank adalah badan usaha yang menghimpun dana dari masyarakat dalam bentuk simpanan dan menyalurkannya kepada masyarakat dalam bentuk kredit dan atau bentuk-bentuk lainnya dalam rangka meningkatkan taraf hidup rakyat banyak. Menurut Jenisnya, bank terdiri dari : a) Bank Umum; b) Bank Perkreditan Rakyat (BPR).

Peraturan Bank Indonesia Nomor: 15/3/PBI/2013 Tentang Transparansi Kondisi Keuangan Bank Perkreditan Rakyat, Bank wajib menyusun dan menyajikan laporan keuangan dengan bentuk dan cakupan sebagaimana ditetapkan dalam Peraturan Bank Indonesia ini, yang terdiri dari : (1) Laporan Tahunan; (2) Laporan Keuangan Publikasi Triwulanan; (3) Laporan Keuangan Publikasi Bulanan; dan (4) Laporan keuangan konsolidasi. Laporan keuangan yang diterbitkan diharapkan mencerminkan kinerja bank tersebut yang sebenarnya. Bank yang memiliki tingkat kinerja yang baik dikatakan memiliki kesehatan yang baik pula.

Penggunaan analisa rasio keuangan sebagai alat untuk mengetahui kondisi kesehatan bank atau yang dikenal dengan Analisis Kinerja Keuangan Bank merupakan penilaian terhadap hasil usaha bank dalam kurun waktu tertentu dan faktor yang mempengaruhinya, dengan menggunakan alat yang disebut CAMEL (Capital, Asset, Management, Earning, Liquidity) Rating System. Model CAMEL ini dapat mengukur tingkat kinerja dan kesehatan dari suatu bank, sehingga Bank Indonesia dapat menilai mana bank yang sehat dan yang tidak sehat agar Bank Indonesia dapat dengan segera melakukan suatu tindakan untuk mencegah terjadinya risiko dari bank yang dinilai mengalami kesulitan yang dapat membahayakan kelangsungan usahanya dan atau sistem perbankan nasional. Selanjutnya kinerja Bank yang baik diharapkan akan

15.

Jurnal Manajemen \& Bisnis Kreatif 
mampu tumbuh dan berkembang dengan baik juga, sehingga mampu memberikan kontribusi bagi perkembangan ekonomi nasional.

Analisis ROA (Return on asset) mengukur kemampuan kinerja perusahaan dalam menghasilkan laba dengan menggunakan total aset (kekayaan) yang dipunyai perusahaan setelah disesuaikan dengan biaya - biaya untuk mendanai aset tersebut. ROA penting bagi bank karena ROA digunakan untuk mengukur efektivitas perusahaan dalam menghasilkan keuntungan dengan memanfaatkan aktiva yang dimilikinya.

Semakin besar ROA maka menunjukkan kinerja perusahaan yang semakin membaik. Rasio - rasio yang mempengaruhi ROA adalah : CAR(Capital Adequacy Ratio), LDR (Loan to Deposit Ratio), NPL(Non Performing Loan), BOPO (Biaya Operasional dan Pendapatan Operasional), NIM (Net Interest Margin), (Pandu Mahardian, 2008; Ponttie Prasnanugraha P, 2007).

Bank Perkreditan Rakyat PT BPR Polin Jaya yang beralamat di Jalan Jenderal Ahmad Yani No.15 A, Dawuan Timur, Karawang, Jawa Barat. Maksud dan tujuan dari perseroan ini adalah sebagai berikut :

a. Menghimpun dana dari masyarakat dalam bentuk Deposito Berjangka dan Tabungan

b. Memberikan kredit bagi pengusaha kecil dan masyarakat pedesaan.

Periode pembukuan Persero ini berjalan dari tanggal 1 Januari sampai dengan 31 Desember dan mulai beroperasi sejak Maret 1992.

Adapun data tentang dinamika pergerakan rasio rasio keuangan PT BPR Polin Jaya periode Tahun 2010 sampai dengan 2014 sebagai berikut :

Tabel 4.1

Rasio Keuangan PT BPR Polin Jaya Tahun 2010 sampai dengan 2014

\begin{tabular}{|l|l|l|l|l|l|l|l|}
\hline Tahun & Bulan & CAR & NPL & NIM & BOPO & LDR & ROA \\
\hline 2010 & Maret & $23,10 \%$ & $3,04 \%$ & $10,66 \%$ & $53,20 \%$ & $172,93 \%$ & $5,98 \%$ \\
\hline & Juni & $21,82 \%$ & $3,24 \%$ & $20,38 \%$ & $52,37 \%$ & $177,51 \%$ & $11,89 \%$ \\
\hline & September & $20,13 \%$ & $3,23 \%$ & $27,97 \%$ & $53,16 \%$ & $184,63 \%$ & $16,48 \%$ \\
\hline & Desember & $18,28 \%$ & $3,36 \%$ & $42,42 \%$ & $44,92 \%$ & $200,16 \%$ & $28,43 \%$ \\
\hline 2011 & Maret & $19,83 \%$ & $4,01 \%$ & $10,35 \%$ & $65,15 \%$ & $162,19 \%$ & $5,22 \%$ \\
\hline & Juni & $19,08 \%$ & $4,24 \%$ & $19,22 \%$ & $67,40 \%$ & $235,82 \%$ & $9,18 \%$ \\
\hline & September & $17,54 \%$ & $4,04 \%$ & $22,18 \%$ & $79,39 \%$ & $255,29 \%$ & $9,24 \%$ \\
\hline & Desember & $15,99 \%$ & $3,98 \%$ & $28,63 \%$ & $75,22 \%$ & $223,77 \%$ & $12,93 \%$ \\
\hline 2012 & Maret & $15,95 \%$ & $4,24 \%$ & $8,60 \%$ & $68,38 \%$ & $230,65 \%$ & $4,25 \%$ \\
\hline & Juni & $15,79 \%$ & $4,71 \%$ & $17,42 \%$ & $66,93 \%$ & $204,34 \%$ & $8,99 \%$ \\
\hline & September & $15,00 \%$ & $6,66 \%$ & $35,42 \%$ & $57,91 \%$ & $242,23 \%$ & $15,41 \%$ \\
\hline
\end{tabular}

16. 


\begin{tabular}{|l|l|l|l|l|l|l|l|}
\hline & Desember & $15,00 \%$ & $6,66 \%$ & $35,42 \%$ & $57,91 \%$ & $242,23 \%$ & $15,41 \%$ \\
\hline 2013 & Maret & $15,18 \%$ & $6,61 \%$ & $9,33 \%$ & $62,90 \%$ & $260,23 \%$ & $4,67 \%$ \\
\hline & Juni & $16,34 \%$ & $7,23 \%$ & $22,57 \%$ & $64,32 \%$ & $239,18 \%$ & $10,81 \%$ \\
\hline & September & $15,04 \%$ & $7,62 \%$ & $31,48 \%$ & $68,26 \%$ & $235,73 \%$ & $14,39 \%$ \\
\hline & Desember & $13,81 \%$ & $4,14 \%$ & $38,55 \%$ & $53,40 \%$ & $160,75 \%$ & $16,31 \%$ \\
\hline 2014 & Maret & $13,81 \%$ & $4,72 \%$ & $37,32 \%$ & $53,40 \%$ & $160,58 \%$ & $15,74 \%$ \\
\hline & Juni & $13,62 \%$ & $5,18 \%$ & $20,62 \%$ & $64,27 \%$ & $139,01 \%$ & $7,52 \%$ \\
\hline & September & $14,10 \%$ & $6,31 \%$ & $31,37 \%$ & $65,44 \%$ & $154,37 \%$ & $11,18 \%$ \\
\hline & Desember & $13,82 \%$ & 7,025 & $41,50 \%$ & $62,41 \%$ & $165,32 \%$ & $16,56 \%$ \\
\hline
\end{tabular}

Sumber : Data Sekunder yang diolah

Berdasarkan tabel pergerakan rasio keuangan yang telah disajikan pada hasil data olah yang dilansir Otoritas Jasa Keuangan dan Bank Indonesia bahwa ROA (Return on Asset) mengalami peningkatan pada tahun 2010 dan mengalami penurunan kembali pada tahun 2014. Selain itu atas dasar latar belakang diatas, juga ditemui adanya fenomena gap dimana berdasarkan hasil perhitungan data rasio keuangan ROA, CAR, NPL, NIM, BOPO, LDR pada tabel diatas, dapat disimpulkan bahwa rata-rata rasio keuangan setiap tahunnya dari tahun 2010 sampai dengan tahun 2014 mengalami fluktuasi data yaitu terjadi kenaikan dan penurunan data dari masing-masing variabel. Hal tersebut tidak menunjukkan adanya kekonsistenan data karena nilai rata - rata berfluktuasi, mengalami kenaikan dan penurunan.

\subsection{Perumusan Masalah}

Dalam penelitian ini pemasalahannya dapat dirumuskan sebagai berikut :

1. Bagaimana pengaruh secara parsial CAR (Capital Adequacy Ratio), NPL (Non Performing Loan), NIM (Net Interest Margin), BOPO (Biaya operasional Pendapatan Operasional) dan LDR (Loan to Deposit Ratio) terhadap ROA (Return on Asset)

2. Bagaimana pengaruh secara simultan CAR (Capital Adequacy Ratio), NPL (Non Performing Loan), NIM (Net Interest Margin), BOPO (Biaya operasional Pendapatan Operasional) dan LDR (Loan to Deposit Ratio) terhadap ROA (Return on Asset)

\subsection{Tujuan Penelitian}

Adapun yang menjadi tujuan dari penelitian ini adalah sebagai berikut:

1. untuk mengetahui, menganalisis dan mengkaji pengaruh secara parsial CAR, NPL, NIM, BOPO dan LDR terhadap ROA.

17. 
2. untuk mengetahui, menganalisis dan mengkaji pengaruh secara simultan CAR, NPL, NIM, BOPO dan LDR terhadap ROA.

\section{BAB II \\ TINJAUAN PUSTAKA, KERANGKA PEMIKIRAN DAN HIPOTESIS}

\subsection{Rasio Keuangan}

Analisis rasio keuangan adalah suatu kegiatan yang dilakukan untuk memperoleh gambaran perkembangan finansial dan posisi finansial perusahaan. Analisis rasio keuangan berguna sebagai analisis intern bagi manajemen perusahaan untuk mengetahui hasil finansial yang telah dicapai guna perencanaan yang akan datang dan juga untuk analisis intern bagi kreditor dan investor untuk menetukan kebijakan pemberian kredit dan penanaman modal suatu perusahaan (Bahtiar Usman,2003).

Capital Adequacy Ratio (CAR) adalah rasio atau perbandingan antara modal bank dengan aktiva tertimbang menurut resiko (ATMR). CAR menjadi pedoman bank dalam melakukan ekspansi di bidang perkreditan.

Adapun rumus Capital Adequacy Ratio berdasarkan Peraturan Bank Indonesia Nomor 8/18/PBI/2006 tanggal 5 Oktober 2006 sebagai berikut :

$$
\mathrm{CAR}=\frac{\text { Modal }}{\text { Aktiva Tertimbang Menurut Resiko }}
$$

Non Performing Loan (NPL) adalah debitur atau kelompok debitur yang masuk dalam golongan 3, 4, 5 dari 5 golongan kredit yaitu debitur yang kurang lancar, diragukan dan macet. Hendaknya selalu diingat bahwa perubahan pengolongan kredit dari kredit lancar menjadi NPL adalah secara bertahap melalui proses penurunan kualitas kredit (Z. Dunil, 2005).

rumus non performing loan berdasarkan Surat Edaran Bank Indonesia Nomor 12/11/DPNP tanggal 31 Maret 2010 sebagai berikut :

$$
\text { Non Performing Loan }=\frac{\text { kredit bermasalah }}{\text { total } \text { kredit }}
$$

18. 
Nett Interest Margin merupakan perbandingan antara pendapatan bunga bersih terhadap rata-rata aktiva produktif. Pendapatan bunga bersih diperoleh dari pendapatan bunga dikurangi beban bunga. Aktiva produktif yang diperhitungkan adalah aktiva produktif yang menghasilkan bunga (interest bearing assets).

rumus Net Interest Margin berdasarkan Surat Edaran Bank Indonesia Nomor 12/11/DPNP tanggal 31 Maret 2010 sebagai berikut :

$$
\text { Net Interest Margin }=\frac{\text { pendapatan bunga bersih }}{\text { rata }- \text { rata aktiva produktif }}
$$

Biaya Operasi dan Pendapatan Operasi merupakan rasio antara biaya operasi terhadap pendapatan operasi. Biaya operasi merupakan biaya yang dikeluarkan oleh bank dalam rangka menjalankan aktivitas usaha utamanya seperti biaya bunga, biaya pemasaran, biaya tenaga kerja dan biaya operasi lainnya. Pendapatan operasi merupakan pendapatan utama bank yaitu pendapatan yang diperoleh dari penempatan dana dalam bentuk kredit dan pendapatan operasi lainnya.

rumus Biaya Operasi dan Pendapatan Operasi berdasarkan Surat Edaran Bank Indonesia Nomor 12/11/DPNP tanggal 31 Maret 2010 sebagai berikut :

$$
\mathrm{BOPO}=\frac{\text { total beban operasional }}{\text { total pendapatan operasional }}
$$

Loan to Deposit Ratio merupakan rasio yang mengukur kemampuan bank untuk memenuhi kewajiban keuangan yang harus dipenuhi. Kewajiban tersebut berupa call money yang harus dipenuhi pada saat adanya kewajiban kliring, dimana pemenuhannya dilakukan dari aktiva lancar yang dimiliki perusahaan (Agus Suyono,2005).

rumus Loan to Deposit Ratio berdasarkan Surat Edaran Bank Indonesia Nomor 12/11/DPNP tanggal 31 Maret 2010 sebagai berikut :

$$
\mathrm{LDR}=\frac{\text { Kredit }}{\text { Dana pihak ketiga }}
$$

Return On Asset (ROA) merupakan kemampuan dari modal yang diinvestasikan ke dalam seluruh aktiva perusahaan untuk menghasilkan keuntungan.

19. 
rumus Return On Asset berdasarkan Surat Edaran Bank Indonesia Nomor 12/11/DPNP tanggal 31 Maret 2010 sebagai berikut :

$$
\mathrm{ROA}=\frac{\text { Laba Sebelum Pajak }}{\text { Rata }- \text { rata Total Asset }}
$$

\subsection{Kerangka Pemikiran}

Kerangka pemikiran dalam penelitian ini didasarkan kepada penelenitian terdahulu sebagai berikut :

1. Pengaruh secara parsial CAR, NPL, NIM, BOPO dan LDR (Loan to Deposit Ratio) terhadap ROA.

Penelitian Agus Suyono (2005) menyatakan bahwa rasio CAR, BOPO, dan LDR berpengaruh signifikan terhadap ROA. Untuk NIM, NPL, pertumbuhan laba operasi dan pertumbuhan kredit tidak menunjukkan hasil yang signifikan terhadap ROA. Penelitian tersebut telah dibuktikan pula oleh penelitian Budi Ponco (2008).

2. Pengaruh secara simultan CAR, NPL, NIM, BOPO dan LDR (Loan to Deposit Ratio) terhadap ROA.

Penelitian Ponttie Pranasnugraha (2007) menunjukna bahwa Variabel Capital Adequacy Ratio (CAR), Biaya Operasi dibanding Pendapatan Operasi (BOPO), Net Interest Margin (NIM), Non Performing Loan (NPL) dan Loan to Deposit Ratio (LDR) secara bersama-sama mempunyai pengaruh yang berarti terhadap Return On Asset (ROA). Hasil penelitian tersebut sejalan dengan penelitian Wisnu Mawardi (2005).

Berdasarkan beberapa referensi penelitian di atas, selanjutnya dapat disusun kerangka model konseptual penelitian sebagai berikut:



20. 


\section{Gambar 1. Model Konseptual Penelitian}

\subsection{Hipotesis}

Berdasarkan kerangka pemikiran tersebut di atas maka dibuat hipotesis penelitian sebagai berikut :

1. Pengaruh secara parsial CAR, NPL, NIM, BOPO dan LDR terhadap ROA

2. Pengaruh secara simultan CAR, NPL, NIM, BOPO dan LDR terhadap ROA

\subsection{Metode Penelitian}

\section{BAB III \\ METODE PENELITIAN}

Penelitian ini menggunakan metode penelitian deskriptif dengan pendekatan analisis kuantitatif. Sebagaimana dikemukakan oleh Sugiyono (2010:53), metode deskriptif adalah suatu rumusan masalah yang berkenaan dengan pertanyaan terhadap keberadaan variabel mandiri, baik hanya pada satu variabel atau lebih (variabel mandiri adalah variabel yang berdiri sendiri, bukan variabel independen karena kalau vaiabel indpenden selalu dipasangkan dengan variabel dependen).

\section{2 opersionalisasi Variabel}

variavel dan definisi operasional variabel dari penelitian ini dapat dilihat pada tabel 3.1 berikut ini.

Tabel 1

Operasional Variabel : Definisi Operasional, Indikator dan Skala Ukur

\begin{tabular}{|c|c|c|c|c|}
\hline No & Variabel & Definisi Operasional & Indikator & $\begin{array}{l}\text { Skala } \\
\text { Ukur }\end{array}$ \\
\hline 1 & CAR & $\begin{array}{l}\text { Perbandingan antara modal } \\
\text { dan aktiva tertimbang } \\
\text { minimum resiko }\end{array}$ & $\frac{\text { Modal }}{\text { ATMR }}$ & $\%$ \\
\hline 2 & NPL & $\begin{array}{l}\text { Perbandingan antara Kredit } \\
\text { dan Dana Pihak Ketiga }\end{array}$ & Dana $\frac{\text { Kredit }}{\text { Pihak Ketiga }}$ & $\%$ \\
\hline 3 & NIM & $\begin{array}{l}\text { Perbandingan antara } \\
\text { Pendapatan Bunga Bersih } \\
\text { dan Aktiva Produktif }\end{array}$ & $\frac{\text { Pendapatan Bunga Bersih }}{\text { Aktiva Produktif }}$ & $\%$ \\
\hline
\end{tabular}

21. 


\begin{tabular}{|c|c|c|c|c|}
\hline 4 & BOPO & $\begin{array}{l}\text { Perbandingan antara Biaya } \\
\text { Operasional dan Pendapat } \\
\text { Operasional }\end{array}$ & $\frac{\text { Biaya Operasional }}{\text { Pendapatan Operasional }}$ & $\%$ \\
\hline 5 & LDR & $\begin{array}{l}\text { Perbandingan antara Kredit } \\
\text { dan Dana Pihak Ketiga }\end{array}$ & Dana $\frac{\text { Kredit }}{\text { Pihak Ketiga }}$ & $\%$ \\
\hline 6 & ROA & $\begin{array}{l}\text { Perbandingan antara Laba } \\
\text { sebelum pajak dan Total } \\
\text { asset }\end{array}$ & $\frac{\text { Laba sebelum pajak }}{\underline{\text { Total Asset }}}$ & $\%$ \\
\hline
\end{tabular}

Sumber : dikaji dari berbagai sumber

\subsection{Sumber Dan Cara Penentuan Data}

data yang digunakan dalam penelitian ini adalah data sekunder. Data berupa laporan keuangan yang dipublikasikan oleh Otoritas Jasa Keuangan dan Bank Indonesia rasio-rasio keuangan bank yang telah diolah terhadap laporan keuangan bank periode 2010 sampai dengan 2014 yang telah diaudit dan kemudian dipublikasikan dalam Direktori Perbankan Otoritas Jasa Keuangan dan Bank Indonesia.

Data/Informasi ditentukan langsung dalam penelitian ini yaitu Laporan Keuangan PT. BPR Polin Jaya tahun 2010 sampai dengan 2014 yang telah dipublikasikan di Website Otoritas Jasa Keuangan dan Bank Indonesia.

\subsection{Teknik pengumpulan data}

Penelitian ini menggunakan teknik pengumpulan data yaitu pengumpulan data sekunder berupa jurnal penelitian yang diperlukan, buku-buku, dan laporan keuangan perbankan dari Direktori Perbankan Indonesia, Sumber Internet dan www.bi.go.id serta www.ojk.go.id untuk menghitung variabel-variabel yang digunakan dalam penelitian

\subsection{Uji Keabsahan Data}

\subsubsection{Uji Normalitas}

Uji normalitas bertujuan untuk menguji salah satu asumsi dasar analisis regresi berganda yaitu variabel dependen dan independen mempunyai distribusi normal atau tidak. Model regresi yang baik adalah memiliki distribusi normal atau mendekati normal. Meskipun normalitas suatu variabel tidak selalu diperlukan dalam analisis akan 
tetapi hasil uji statistik akan lebih baik jika semua variabel terdistribusi normal (Imam Ghozali, 2013: 30).

Untuk menguji apakah data-data berdistribusi normal atau tidak, maka dapat dilakukan analisis grafik dan analisis statistik (Imam Ghozali, 2013: 160).

1. Analisis Grafik

Salah satu cara termudah untuk melihat normalitas residual adalah dengan melihat histogram yang membandingkan antara data observasi dengan distribusi yang mendekati normal. Namun jika hanya melihat histogram dapat membingungkan, khususnya untuk jumlah sampel yang kecil. Metode lain yang dapat digunakan adalah dengan melihat normal probability plot yang membandingkan distribusi kumulatif dari distribusi normal.

\section{Analisis Statistik}

Salah satu cara mendeteksi normalitas data ialah dengan melakukan analisis statistik yang salah satunya dapat dilihat melalui Kolmogorov-Smirnov test (K-S). Apabila signifikansi variabel lebih besar dari alpha 5\%, maka distribusi data normal. Namun apabila signifikansi variabel kurang dari 5\%, maka distribusi data tidak normal.

\subsubsection{Uji Asumsi Klasik}

Mengingat data penelitian yang digunakan adalah data sekunder, maka untuk memenuhi syarat yang ditentukan sebelum dilakukan uji hipotesis melalui uji-t dan ujif serta untuk menentukan ketepatan model maka perlu dilakukan pengujian atas beberapa asumsi klasik yang digunakan yaitu uji multikolinearitas, uji heteroskedastisitas, dan uji autokolerasi (Budi Ponco, ST: 2008).

\subsubsection{Uji Multikolinearitas}

Uji multikolinearitas bertujuan untuk menguji model regresi apakah ditemukan korelasi antar variabel independen (Ghozali : 2001 dalam Budi Ponco, ST: 2008). Untuk mendeteksi ada atau tidaknya multikolinearitas adalah sebagai berikut:

a) Memperhatikan matriks kolerasi yang dihasilkan pada saat pengolahan data. Apabila nilai matriks kolerasi tidak ada yang lebih besar dari 0,5 maka data terlepas dari gejala multikolinearitas.

b) Apabila nilai VIF berada di bawah 10 dan nilai tolerance maka model regresi tersebut tidak terdapat multikolinearitas (Imam Ghozali : 2001 dalam Ahmad Buyung Nusantara : 2009).

\subsubsection{Uji Heterokedastisitas}

23. 
Uji heterokedastisitas bertujuan untuk menguji apakah sebuah model regresi terjadi ketidaksamaan varians dari residual dari satu pengamatan ke pengamatan yang lain. Jika varians dari residual satu pengamatan ke pengamatan yang lain itu berbeda maka disebut heterokedastisitas. Adapun jika varians dari residual satu pengamatan ke pengamatan yang lain itu tetap maka disebut homokedastisitas. Model regresi yang baik itu adalah jika tidak terjadi heterokedastisitas. Untuk mengetahui ada tidaknya heterokedastisitas dalam model regresi salah satu caranya adalah dengan cara melihat Scatter Plot antara nilai prediksi variabel terikat dengan residualnya.

\subsubsection{Uji Autokorelasi}

Uji autokorelasi dilakukan untuk menguji apakah di dalam model regresi linear terdapat korelasi antara kesalahan pengganggu pada periode $\mathrm{t}$ dengan kesalahan periode t-1 (sebelumnya). Maksud dari autokorelasi adalah terdapat korelasi antar anggota sampel yang diurutkan berdasarkan waktu saling berkorelasi. Jika terjadi korelasi, maka dinamakan ada masalah autokorelasi. Autokorelasi muncul dikarenakan observasi yang bermurutan sepanjang waktu berkaitan satu sama lain. Masalah ini timbul karena residual (kesalahaan pengganggu) tidak bebas satu observasi ke observasi yang lainnya. Model regresi yang baik itu adalah jika bebas autokorelasi. Untuk menguji ada tidaknya autokorelasi dalam data adalah dengan melakukan Durbin-Watson Test. Adapun ketentuan uji Durbin-Watson (DW) adalah sebagai berikut (Ghozali : 2005 dalam Diana Puspitasari, SE : 2009):

Tabel 3.3

Tabel DW Test

\begin{tabular}{|l|l|l|}
\hline \multicolumn{1}{|c|}{ Hipotesis Nol } & \multicolumn{1}{c|}{ Keputusan } & \multicolumn{1}{c|}{ Jika } \\
\hline Tidak ada autokorelasi positif & Tolak & $0<\mathrm{d}<\mathrm{dl}$ \\
\hline Tidak ada autokorelasi positif & Tidak ada keputusan & $\mathrm{dl} \leq \mathrm{d} \leq \mathrm{du}$ \\
\hline Tidak ada korelasi positif & Tolak & $4-\mathrm{dl}<\mathrm{d}<4$ \\
\hline Tidak ada korelasi positif & Tidak ada keputusan & $4-\mathrm{du} \leq \mathrm{d} \leq-\mathrm{dl}$ \\
\hline Tidak ada autokorelasi positif atau negatif & Tidak ditolak & $\mathrm{du}-\mathrm{d}<4<\mathrm{du}$ \\
\hline
\end{tabular}

Sumber : (Ghozali : 2005)

\subsection{Rancangan Analisis dan Uji Hipotesis}

\subsubsection{Rancangan Analisis}

\subsubsection{Analisis Regresi Berganda}

Analisis regresi ganda digunakan untuk meramalkan bagaimana keadaan (naik turunnya) variabel dependen (kriterium) bila dua atau lebih variabel independen

24. 
sebagai faktor prediktor dimanipulasi (dinaikturunkan nilainya). Analisis regresi ganda ini akan dilakukan apabila jumlah variabel independennya berjumlah minimal 2 (Sugiyono, 275: 2013).

Dalam penelitian ini variabel independennya adalah CAR, NPF, dan BOPO. Sedangkan variabel dependennya adalah ROA. Model hubungan ROA selaku variabel dependen dengan CAR, NPL, NIM, BOPO dan LDR selaku variabel-variabel independen adalah:

$$
\mathrm{Y}=\mathrm{a}+\mathrm{b} 1 \mathrm{X} 1+\mathrm{b} 2 \mathrm{X} 2+\mathrm{b} 3 \mathrm{X} 3+\mathrm{b} 4 \mathrm{X} 4+\mathrm{b} 5 \mathrm{X} 5+\mathrm{e}
$$

Dimana:

Y adalah variabel dependen

a adalah koefisien konstanta

$\mathrm{X} 1$ adalah variabel independen pertama

$\mathrm{X} 2$ adalah variabel independen kedua

$\mathrm{X} 3$ adalah variabel independen ketiga

$\mathrm{X} 4$ adalah variabel independen keempat

X5 adalah variabel independen kelima

e adalah error (nilai kesalahan)

Berdasarkan persamaan tersebut maka penelitian ini diuji dengan menggunakan rumus sebagai berikut:

$$
\begin{gathered}
\mathrm{ROA}=\mathrm{a}+\mathrm{b} 1 \mathrm{CAR}+\mathrm{b} 2 \mathrm{NPL}+\mathrm{b} 3 \mathrm{NIM}+\mathrm{b} 4 \mathrm{BOPO}+\mathrm{b} 5 \mathrm{LDR}+\mathrm{e} \\
\mathrm{e} \quad=\text { kesalahan residual (error) }
\end{gathered}
$$

\subsubsection{Analisis Koefisien Determinasi $\left(\mathbf{R}^{2}\right)$}

Koefisien determinasi $\left(\mathrm{R}^{2}\right)$ digunakan untuk mengetahui sampai sejauh mana keseluruhan variabel independen dapat menjelaskan variabel dependen. Apabila nilai koefisien determinasi semakin mendekati 1, maka pengaruh variabel independen terhadap variabel dependen adalah kuat. Ini berarti variabel-variabel independen memberikan hampir semua informasi yang dibutuhkan untuk memprediksi variasi variabel dependen. Sedangkan nilai koefisiensi determinasi yang kecil berarti menunjukkan bahwa kemampuan variabel-variabel independen dalam menjelaskan variasi variabel dependen adalah terbatas (Ghozali : 2005 dalam Diana Puspitasari, SE : 2009).

\subsubsection{Uji Hipotesis}

25.

Jurnal Manajemen \& Bisnis Kreatif 
Untuk melakukan pengujian terhadap hipotesis-hipotesis yang diajukan, digunakan analisis regresi melalui Uji T maupun Uji F. Analisis regresi ini bertujuan untuk mengetahui pengaruh variabel-variabel independen terhadap variabel dependen, baik secara parsial maupun secara simultan, serta untuk mengetahui besarnya dominasi variabel-variabel independen terhadap variabel dependen.

\subsubsection{Uji T}

Uji $\mathrm{T}$ bertujuan untuk mengetahui tingkat signifikansi pengaruh tiap-tiap variabel independen terhadap variabel independen terikat dengan asumsi bebas yang lain tidak berubah (cateris paribus). Uji T ini dilakukan dengan syarat (Adi Stiawan : 2009) :

1. Jika $-\mathrm{t}$ tabel $<\mathrm{t}$ hitung $<\mathrm{t}$ tabel, maka Ho diterima, yaitu variabel independen tidak berpengaruh terhadap variabel dependen.

2. Jika $t$ hitung $>t$ tabel atau $-t>-t$ tabel, maka Ho ditolak yang berarti variabel independen berpengaruh signifikan terhadap variabel dependen.

3. Mengamati nilai signifikansi t pada tingkat $\alpha$ sebesar $5 \%$.

a. Jika signifikansi t $<0,05$ maka Ho ditolak, yaitu variabel independen berpengaruh signifikan terhadap variabel dependen.

b. Jika signifikansi t $>0,05$ maka Ho diterima, yaitu variabel independen tidak berpengaruh signifikan terhadap variabel dependen.

Uji T ini akan digunakan untuk menguji seberapa besar pengaruh variabel CAR terhadap variabel ROA, seberapa besar pengaruh variabel NPF terhadap variabel ROA, seberapa besar pengaruh variabel BOPO terhadap variabel ROA.

\subsubsection{Uji F}

Uji $\mathrm{F}$ bertujuan untuk mengetahui signifikansi seluruh variabel independen secara bersama-sama terhadap variabel dependen (Ghozali : 2004 dalam Ahmad Buyung Nusantara : 2009). Uji F ini dilakukan dengan syarat (Adi Stiawan : 2009):

1. Jika $F$ hitung < F tabel, maka Ho diterima, yaitu variabel-variabel independen secara simultan tidak berpengaruh terhadap variabel dependen.

2. Jika $\mathrm{F}$ hitung $>\mathrm{F}$ tabel, maka Ho ditolak yaitu variabel-variabel independen secara simultan berpengaruh terhadap variabel dependen.

3. Mengamati nilai signifikansi $\mathrm{F}$ pada tingkat $\alpha$ sebesar $5 \%$.

a. Jika signifikansi $\mathrm{F}<0,05$ maka Ho ditolak yang berarti variabel-variabel independen secara simultan berpengaruh terhadap variabel dependen.

b. Jika signifikansi F > 0,05 maka Ho diterima yang berarti variabel-variabel independen secara simultan tidak berpengaruh terhadap variabel dependen.

26. 
Uji F digunakan untuk menguji signifikansi pengaruh CAR (Capital Adequacy Ratio), Biaya Operasi/Pendapatan Operasi (BOPO), NPL (Non Performing Loan), NIM (Net Interest Margin), dan LDR (Loan to Deposit Ratio) terhadap Return on Asset (ROA) secara simultan.

\section{BAB IV \\ HASIL ANALISIS DAN UJI HIPOTESIS}

\subsection{Analisis Verifikatif dan Uji Hipotesis \\ 4.1.1 Uji Asumsi Klasik \\ a. Uji Normalitas}

Uji normalitas bertujuan untuk menguji apakah dalam model regresi, variable residual memiliki distribusi normal. Untuk menguji apakah distribusi data normal atau tidak, ada dua cara untuk mendeteksinya, yaitu dengan analisis grafik dan uji statistik. Analisis grafik merupakan cara yang termudah untuk melihat normalitas residual adalah dengan melihat grafik histogram

yang membandingkan antara data observasi dengan distribusi yang mendekati distribusi normal.

\section{Dependent Variable: ROA}



Gambar 4.1

Grafik Histogram

Sumber : Data Sekunder yang diolah 
Dari gambar 4.1. terlihat bahwa pola distribusi mendekati normal, akan tetapi jika kesimpulan normal tidaknya data hanya dilihat dari grafik histogram, maka hal ini dapat menyesatkan khususnya untuk jumlah sampel yang kecil. Metode lain yang digunakan dalam analisis grafik adalah dengan melihat normal probability plot yang membandingkan distribusi kumulatif dari distribusi normal. Jika distribusi data residual normal, maka garis yang akan menggambarkan data sesungguhnya akan mengikuti garis diagonalnya.

\section{Normal P-P Plot of Regression Standardized Residual}



Gambar 4.2

Normal Probability Plot

Sumber : Data Sekunder yang diolah

Grafik probabilitas pada gambar 4.2. diatas sekilas memang terlihat normal karena distribusi data residualnya terlihat mendekati garis normalnya. Namun biasanya hal ini menyesatkan, oleh karena itu analisis statistik digunakan untuk memastikan apakah data tersebut benar-benar normal. Pengujian normalitas data secara analisis statistik dilakukan dengan menggunakan Uji Kolmogorov-Smirnov. Secara multivariat pengujian normalitas data dilakukan terhadap nilai residualnya. Data yang berdistribusi normal ditunjukkan dengan nilai signifikansi diatas 0,05 atau 5\% (Ghozali,2005).

Hasil pengujian normalitas pada pengujian terhadap 20 data terlihat dalam Tabel 4.3 berikut : 
Tabel 4.3

\begin{tabular}{|c|c|c|c|c|c|c|c|}
\hline & & CAR & NPL & NIM & BOPO & LDR & $\mathrm{ROA}$ \\
\hline N & & 20 & 20 & 20 & 20 & 20 & 20 \\
\hline \multirow[t]{2}{*}{ Normal Parameters ${ }^{a}$} & Mean & 16.6615 & 5.0110 & 25.5705 & 61.8170 & $2.0235 \mathrm{E} 2$ & 12.0075 \\
\hline & Std. Deviation & 2.82553 & 1.51420 & 1.10175E1 & 8.47461 & $3.89080 \mathrm{E} 1$ & 5.67737 \\
\hline \multirow[t]{3}{*}{ MostExtreme Differences } & Absolute & .195 & .195 & .114 & .140 & .167 & .164 \\
\hline & Positive & .195 & .195 & .112 & .140 & .138 & .164 \\
\hline & Negative & -.141 & -.155 & -.114 & -.128 & -.167 & -.086 \\
\hline Kolmogorov-SmirnovZ & & .873 & .871 & .511 & .625 & .745 & .735 \\
\hline Asymp. Sig. (2-tailed) & & .431 & .434 & .956 & .830 & .636 & .652 \\
\hline
\end{tabular}

Sumber : Data Sekunder yang diolah

Berdasarkan hasil pada tabel diatas, menunjukkan bahwa data sudah terdistribusi normal. Hal ini ditunjukkan dengan nilai Kolmogorov-Smirnov adalah 0,511 sampai dengan 0,873 dan signifikan pada 0,431 sampai dengan 0,956. Hal ini berarti data residual terdistribusi secara normal, karena nilai signifikansinya lebih dari 0,05 . Sehingga untuk uji asumsi klasik selanjutnya menggunakan persamaan regresi ROA = f (CAR, NPL, NIM, BOPO, LDR).

\section{b. Uji Multikolinearitas}

Uji multikolinearitas bertujuan untuk menguji apakah model regresi ditemukan adanya korelasi antar variable bebas (independen). Jika variable independen saling berkorelasi, maka variable-variabel ini tidak orthogonal. Variable orthogonal adalah variable independen yang nilai korelasi antar sesama variable independen sama dengan nol (Ghozali, 2006). Dalam penelitian ini menggunakan persamaan regresi $R O A=f$ (CAR, NPL, NIM, BOPO, LDR). Untuk mengetahui apakah terjadi multikolinearitas dapat dilihat dari nilai VIF yang terdapat pada masing-masing variabel seperti terlihat pada Tabel 4.4. berikut: 
Tabel 4.4

\section{Hasil Uji Multikolinearitas}

\begin{tabular}{|c|c|c|c|c|c|c|c|c|}
\hline \multicolumn{9}{|c|}{ Coefficients $^{\mathrm{a}}$} \\
\hline \multirow{2}{*}{\multicolumn{2}{|c|}{ Model }} & \multicolumn{2}{|c|}{ Unstandardized Coefficients } & $\begin{array}{l}\text { Standardized } \\
\text { Coefficients }\end{array}$ & \multirow[b]{2}{*}{$\mathrm{t}$} & \multirow[b]{2}{*}{ Sig. } & \multicolumn{2}{|c|}{ Collinearity Statistics } \\
\hline & & $\mathrm{B}$ & Std. Error & Beta & & & Tolerance & VIF \\
\hline \multirow[t]{6}{*}{1} & (Constant) & 2.160 & 7.769 & & .278 & .785 & & \\
\hline & CAR & .228 & .238 & .113 & .958 & .354 & .374 & 2.675 \\
\hline & NPL & -.675 & .397 & -.180 & -1.700 & .111 & .467 & 2.143 \\
\hline & NIM & .486 & .050 & .943 & 9.716 & .000 & .555 & 1.800 \\
\hline & BOPO & -.152 & .064 & -.226 & -2.357 & .033 & .567 & 1.764 \\
\hline & LDR & .032 & .013 & .216 & 2.504 & .025 & .700 & 1.429 \\
\hline
\end{tabular}

a. Dependent Variable: ROA

Sumber : Data Sekunder yang diolah

Suatu model regresi dinyatakan bebas dari multikolinearitas adalah jika mempunyai nilai Tolerance dibawah 1 dan nilai VIF dibawah 10. Dari tabel tersebut diperoleh bahwa semua variabel bebas memiliki nilai Tolerance berada dibawah 1 dan nilai VIF jauh di bawah angka 10. Dengan demikian dalam model ini tidak ada masalah multikolinieritas. Kesimpulan ini didukung dengan hasil koefisien korelasi antar variabel seperti pada tabel 4.5. dibawah ini :

Tabel 4.5

Hasil Besaran Antar Variabel

Coefficient Correlations ${ }^{*}$

\begin{tabular}{|lll|r|r|r|r|r|}
\hline Madel & & \multicolumn{1}{c|}{ LDR } & \multicolumn{1}{c|}{ CAR } & \multicolumn{1}{c|}{ BOPO } & \multicolumn{1}{c|}{ NIM } & \multicolumn{1}{c|}{ NPL } \\
\hline 1 & Correlations & LDR & 1.000 & -.305 & -.368 & -.041 & -.391 \\
& CAR & -.305 & 1.000 & .425 & .490 & .611 \\
& BOPO & -.368 & .425 & 1.000 & .519 & .067 \\
& NIM & -.041 & .490 & .519 & 1.000 & .025 \\
& NPL & -.391 & .611 & .067 & .025 & 1.000 \\
\hline \multirow{2}{*}{ Covariances } & LDR & .000 & .000 & .000 & $-2.564 \mathrm{E}-5$ & -.002 \\
& CAR & .000 & .056 & .007 & .006 & .058 \\
& BOPO & .000 & .007 & .004 & .002 & .002 \\
& NIM & $-2.564 \mathrm{E}-5$ & .006 & .002 & .002 & .000 \\
& NPL & -.002 & .058 & .002 & .000 & .158 \\
\hline
\end{tabular}

a. Dependent Variable: ROA

Sumber : Data Sekunder yang diolah

30. 
Melihat besaran (koefisien) korelasi antar variable diatas, tampak bahwa hanya variabel CAR yang mempunyai korelasi yang cukup tinggi terhadap variabel BOPO, yaitu dengan koefisien 0,611 atau sekitar $61,1 \%$. Oleh karena korelasi ini masih dibawah 95\%, maka dapat dikatakan tidak terjadi multikolinearitas.

\section{c. Uji Heteroskedastisitas}

Uji heteroskedastisitas bertujuan untuk menguji apakah dalam model regresi terjadi ketidaksamaan varian dari residual satu pengamatan ke pengamatan yang lain. Jika varian dari residual satu pengamatan kepengamatan yang lain tetap, maka disebut homoskedastisitas dan jika berbeda akan disebut heteroskedastisitas.

Model regresi yang baik adalah model yang tidak terjadi heteroskedastisitas (Ghozali, 2005).

Untuk menentukan heteroskedastisitas dapat menggunakan grafik scatterplot, titik-titik yang terbentuk harus menyebar secara acak, tersebar baik diatas maupun dibawah angka 0 pada sumbu $\mathrm{Y}$, bila kondisi ini terpenuhi maka tidak terjadi heteroskedastisitas dan model regresi layak digunakan. Hasil uji heteroskedastisitas dengan menggunakan grafik scatterplot di tunjukan pada gambar 4.3 sebagai berikut:

Gambar 4.3

Grafik Scatterplot 


\section{Scatterplot}

Dependent Variable: ROA

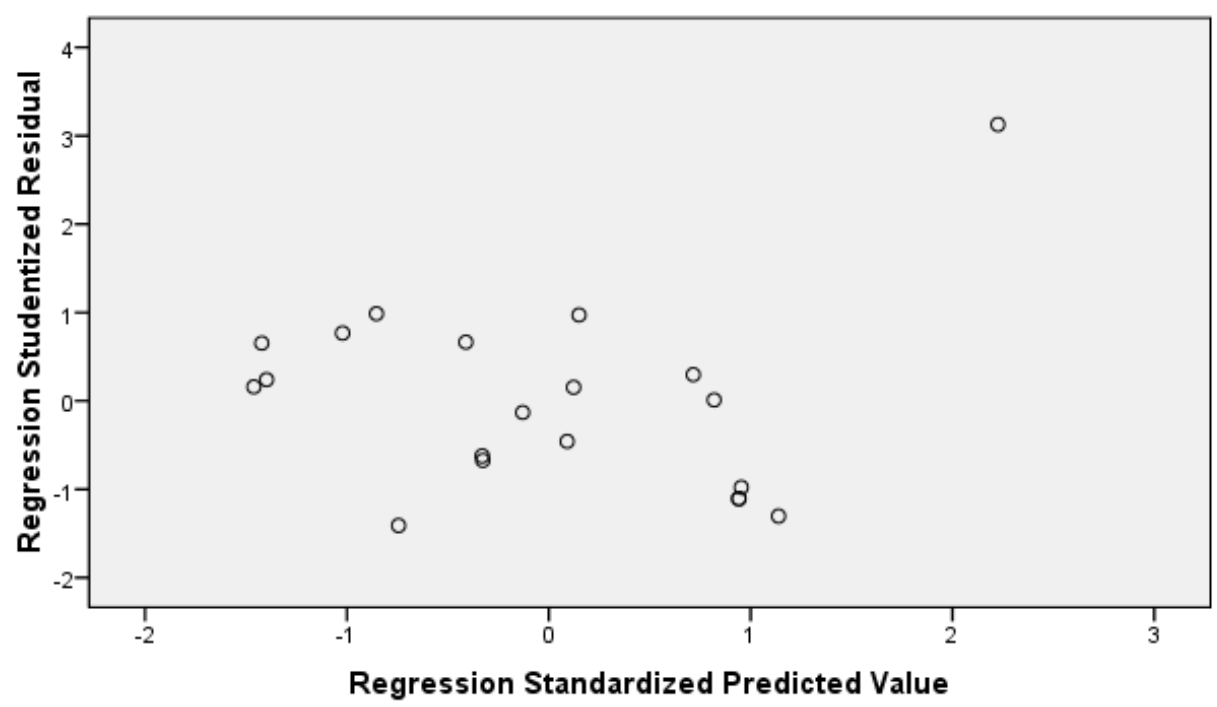

Sumber : Data Sekunder yang diolah

Dari grafik scatterplot terlihat bahwa titik-titik menyebar secara acak serta tersebar baik diatas maupun dibawah angka 0 pada sumbu Y. Dengan demikian dapat disimpulkan bahwa model regresi ini tidak terjadi heteroskedastisitas. Akan tetapi analisis dengan grafik plot memiliki kelemahan dalam keakuratan menginterpretasikannya, oleh sebab itu perlu dilakukan uji statistic untuk lebih menjamin keakuratan hasil.

Uji Koefisien korelasi Spearman's rho yaitu menkorelasikan variabel independen dengan nilai unstandardized residual. Pengujian menggunakan tingkat signifikansi 0,05 dengan uji 2 sisi. Jika korelasi antara variabel independen dengan residual di dapat signifikansi lebih dari 0,05 maka dapat dikatakan bahwa tidak terjadi masalah heteroskedastisitas. Hasil uji heteroskedastisitas dengan menggunakan Tabel Uji Koefisien korelasi Spearman's rho scatterplot di tunjukan pada Tabel 4.6 sebagai berikut:

Tabel 4.6

Hasil uji kofisien korelasi Spearman's rho 


\begin{tabular}{|c|c|c|c|c|c|c|c|c|}
\hline \multicolumn{9}{|c|}{ Correlations } \\
\hline & & & CAR & NPL & $\mathrm{N} \| \mathrm{M}$ & $\mathrm{BOPO}$ & LDR & $\begin{array}{l}\text { Unstandardiz } \\
\text { ed Residual }\end{array}$ \\
\hline \multirow[t]{18}{*}{ Spearman's rho } & \multirow[t]{3}{*}{ CAR } & Correlation Coefficient & 1.000 & $-.669^{\prime \prime}$ & $-.479^{\prime}$ & -.092 & .251 & .084 \\
\hline & & Sig. (2-tailed) & & .001 & .033 & .700 & .285 & .724 \\
\hline & & $N$ & 20 & 20 & 20 & 20 & 20 & 20 \\
\hline & \multirow[t]{3}{*}{ NPL } & Correlation Coefficient & $-.669 "$ & 1.000 & .259 & .290 & .260 & .120 \\
\hline & & Sig. (2-tailed) & .001 & & .270 & .215 & .269 & .615 \\
\hline & & N & 20 & 20 & 20 & 20 & 20 & 20 \\
\hline & \multirow[t]{3}{*}{ NIM } & Correlation Coefficient & $-.479^{\circ}$ & .259 & 1.000 & -.364 & -.187 & -.147 \\
\hline & & Sig. (2-tailed) & .033 & .270 & & .114 & .429 & .537 \\
\hline & & $N$ & 20 & 20 & 20 & 20 & 20 & 20 \\
\hline & \multirow[t]{3}{*}{ BOPO } & Correlation Coefficient & -.092 & .290 & -.364 & 1.000 & .319 & .211 \\
\hline & & Sig. (2-tailed) & .700 & .215 & .114 & & .170 & .372 \\
\hline & & N & 20 & 20 & 20 & 20 & 20 & 20 \\
\hline & \multirow[t]{3}{*}{ LDR } & Correlation Coefficient & .251 & .260 & -.187 & .319 & 1.000 & -.007 \\
\hline & & Sig. (2-tailed) & .285 & .269 & .429 & .170 & & .977 \\
\hline & & $\mathrm{N}$ & 20 & 20 & 20 & 20 & 20 & 20 \\
\hline & \multirow[t]{3}{*}{ Unstandardized Residual } & Correlation Coefficient & .084 & .120 & -.147 & .211 & -.007 & 1.000 \\
\hline & & Sig. (2-tailed) & .724 & .615 & .537 & .372 & .977 & \\
\hline & & $\mathrm{N}$ & 20 & 20 & 20 & 20 & 20 & 20 \\
\hline
\end{tabular}

*. Correlation is significant at the 0.01 level (2-tailed)

*. Correlation is significant at the 0.05 level (2-tailed)

Sumber Data Sekunder yang diolah

Berdasarkan hasil diatas dapat diketahui bahwa nilai korelasi kelima variabel independen dengan Unstandardized Residual memiliki nilai signifikasi lebih dari 0,05. Karena signifikansi lebih dari 0,05, maka dapat disimpulkan bahwa tidak terjadi masalah heteroskedastisitas pada model regresi.

\section{d. Uji Autokorelasi}

Uji autokorelasi bertujuan untuk menguji apakah dalam model regresi linear ada korelasi antara kesalahan pengganggu pada periode t-1 (sebelumnya). Menurut Ghozali, (2005), model regresi yang baik adalah regresi yang bebas dari autokorelasi. Untuk mengetahui ada tidaknya autokorelasi kita harus melihat nilai uji D-W dengan ketentuan sebagai berikut :

Tabel 4.7

Uji Durbin-Watson

Model Summary ${ }^{\mathrm{b}}$

\begin{tabular}{|l|r|r|r|r|r|}
\hline Model & $\mathrm{R}$ & R Square & Adjusted R Square & $\begin{array}{c}\text { Std. Error of the } \\
\text { Estimate }\end{array}$ & Durbin-Watson \\
\hline 1 & $.963^{\mathrm{a}}$ & .927 & .901 & 1.78961 & 1.600 \\
\hline
\end{tabular}

a. Predictors: (Constant), LDR, CAR, BOPO, NIM, NPL

b. Dependent Variable: ROA

Sumber : Data Sekunder yang diolah

33. 
Berdasar hasil analisis regresi diperoleh nilai hitung Durbin Watson sebesar 1,600; Sedangkan besarnya DW-tabel: $d l$ (batas luar) $=0,7918 ; d u($ batas dalam $)=1.99808 ; 5$ $-d u=4,0092$; dan $5-d l=4,2082$; maka dari perhitungan disimpulkan bahwa DWtest terletak pada daerah uji. Hal ini dapat dilihat pada gambar 4.4 sebagai berikut:

Gambar 4.4

Hasil Uji Durbin-Watson

\begin{tabular}{|l|l|l|l|c|c|}
$\begin{array}{l}\text { Autokorelasi } \\
\text { Positif }\end{array}$ & \multicolumn{2}{|c|}{ Daerah ragu ragu } & Tidak Ada Autokorelasi & $\begin{array}{l}\text { Daerah } \\
\text { ragu ragu }\end{array}$ & $\begin{array}{l}\text { Autokorelasi } \\
\text { Negatif }\end{array}$ \\
\hline 0 & & & & 4.092 & 4.2082
\end{tabular}

Sumber : Data Sekunder yang diolah

Dari Hasil uji Durbin -Watson diatas didapat nilai DW yang menghasilakn dari model regresi adalah 1.600. sedangkan dari tabel DW dengan signifiknasi 0,05 dan jumlah data $(\mathrm{n})=20$, sedangkan $\mathrm{k}=5$ ( $\mathrm{K}$ adalah jumlah variabel independen) diperoleh $\mathrm{dL}$ sebesar 0,7918 dan dU sebesar 1,9908 (lihat lampiran). Karena nilai DW (1.600) berada pada daerah antara $\mathrm{dL}$ dan $\mathrm{dU}$, maka tidak menghasilkan kesimpulan yang pasti (berada di daerah keragu-raguan)

\subsection{Hasil Analisis Regresi}

Berdasar output SPSS secara parsial pengaruh dari kelima variabel independen yaitu CAR, NPL, NIM, BOPO, dan LDR terhadap ROA ditunjukkan pada tabel 4.8 sebagai berikut:

Tabel 4.8

Hasil Perhitungan Regresi Parsial

34. 


\begin{tabular}{|c|c|c|c|c|c|c|}
\hline \multicolumn{7}{|c|}{ Coefficients $^{\mathrm{a}}$} \\
\hline \multirow{2}{*}{\multicolumn{2}{|c|}{ Model }} & \multicolumn{2}{|c|}{ Unstandardized Coefficients } & \multirow{2}{*}{$\begin{array}{l}\text { Standardized } \\
\text { Coefficients } \\
\text { Beta } \\
\end{array}$} & \multirow[b]{2}{*}{$\mathrm{t}$} & \multirow[b]{2}{*}{ Sig. } \\
\hline & & $\mathrm{B}$ & Std. Error & & & \\
\hline \multirow[t]{6}{*}{1} & (Constant) & 2.160 & 7.769 & & .278 & .785 \\
\hline & CAR & .228 & .238 & .113 & .958 & .354 \\
\hline & NPL & -.675 & .397 & -.180 & -1.700 & .111 \\
\hline & NIM & .486 & .050 & .943 & 9.716 & .000 \\
\hline & BOPO & -.152 & .064 & -.226 & -2.357 & .033 \\
\hline & LDR & .032 & .013 & .216 & 2.504 & .025 \\
\hline
\end{tabular}

a. DependentVariable:ROA

Sumber : Data Sekunder yang diolah

Dengan melihat tabel 4.8 diatas, dapat disusun persamaan regresi linear berganda sebagai berikut:

$\mathrm{ROA}=2,160+0,228 \mathrm{CAR}-0,675 \mathrm{NPL}+0,486 \mathrm{NIM}-0,152 \mathrm{BOPO}+0,032$ LDR

Berdasarkan persamaan regresi linear berganda diatas, diketahui mempunyai konstanta sebesar 2,160. Hal ini menunjukkan bahwa jika variabel-variabel independen diasumsikan dalam keadaan tetap, maka variabel dependen (ROA) akan naik sebesar 2,160\%. Kemudian untuk arah tanda dan signifikansinya, variable CAR, NIM, dan LDR mempunyai arah positif dan hanya CAR yang tidak signifikan terhadap ROA, sementara variabel NPL dan BOPO mempunyai arah yang negatif tetapi NPL tidak signifikan terhadap variabel ROA sedangkan BOPO signifikan terhadap ROA. Dengan demikian hasil analisis pengaruh variabel independen terhadap variabel dependen yang telah dilakukan ini sebagian besar sesuai dengan kerangka pemikiran yang diajukan oleh peneliti, baik arah tanda maupun signifikansinya. Hanya terdapat dua variabel independen yang tidak signifikan terhadap variabel dependennya, yaitu CAR dan NPL

\subsection{Pengujian Hipotesis (Uji t)}

Dari hasil analisis regresi pada tabel 4.8. tampak bahwa sebagian besar variabel independen berpengaruh signifikan terhadap variabel dependennya, yaitu ROA. Hal ini dibuktikan dengan tingkat signifikansi yang diperoleh variabel independen sebagian besar kurang dari 0,05. Hanya variabel CAR dan NPL nilai signifikansi lebih besar dari 0,05, yaitu sebesar 0,354 dan 0,111 sehingga dapat dipastikan bahwa CAR dan NPL tidak berpengaruh signifikan terhadap variabel dependennya.

\subsection{Pengaruh secara parsial CAR terhadap ROA}

35. 
Hipotesis pertama menyatakan bahwa Capital Adequacy Ratio (CAR) berpengaruh terhadap Return on Asset (ROA). Dari hasil penelitian diperoleh nilai signifikansi sebesar 0,354 , sedangkan koefisien regresinya sebesar 0,228 . Hal ini menunjukkan bahwa CAR memiliki pengaruh positif terhadap ROA tetapi tidak signifikan, karena nilai signifikansinya lebih besar dari 0,05 yaitu sebesar 0,354 . Untuk koefisien regresi sebesar 0,228 berarti setiap kenaikan CAR sebesar $1 \%$ akan meningkatkan ROA sebesar $0,228 \%$. Dengan demikian hipotesis pertama yang menyatakan bahwa Capital Adequacy Ratio memiliki pengaruh positif terhadap Return on Asset diterima.

\subsection{Pengaruh secara parsial NPL terhadap ROA}

Hipotesis pengaruh NPL terhadap ROA menyatakan bahwa non performing loan (NPL) berpengaruh negatif terhadap Return on Asset (ROA). Dari hasil penelitian diperoleh nilai signifikansi sebesar 0,111 , sedangkan koefisien regresinya sebesar 0,675 . Dilihat dari tingkat signifikansinya, menunjukkan bahwa hasilnya tidak signifikan karena nilai signifikansinya lebih besar dari 0,05, yaitu sebesar 0,111. Karena tingkat signifikansinya melebihi dari $0,05 \%$ maka dalam hal ini pengaruh NPL terhadap ROA tidak dapat diartikan. Sehingga dapat disimpulkan bahwa non performing loan (NPL) berpengaruh negative terhadap Return on Asset (ROA). Dengan demikian hipotesa pengaruh NPL terhadap ROA yang menyatakan bahwa non performing loan (NPL) berpengaruh negatif terhadap Return on Asset (ROA) dapat diterima.

\subsection{Pengaruh secara parsial NIM terhadap ROA}

Hipotesis pengaruh NIM terhadap ROA menyatakan bahwa net interest margin (NIM) berpengaruh positif terhadap return on asset (ROA). Dari hasil penelitian diperoleh nilai signifikansi sebesar 0,000 , sedangkan koefisien regresinya sebesar 0,486 . Hal ini menunjukkan bahwa NIM memiliki pengaruh positif terhadap ROA serta signifikan, karena nilai signifikansinya lebih kecil dari 0,05 yaitu sebesar 0,000 . Untuk koefisien regresi sebesar 0,486 berarti setiap penambahan NIM sebesar $1 \%$ akan meningkatkan ROA sebesar 0,486\%. Dengan demikian hipotesis pengaruh NIM terhadap ROA yang menyatakan bahwa net interest margin memiliki pengaruh yang positif terhadap Return on Asset diterima.

\subsection{Pengaruh secara parsial BOPO terhadap ROA}

Hipotesis pengaruh BOPO terhadap ROA menyatakan bahwa efisiensi operasi (BOPO) berpengaruh negatif terhadap Return on Asset (ROA). Dari hasil penelitian diperoleh nilai signifikansi sebesar 0,033 , sedangkan koefisien regresinya sebesar 0,152 . Hal ini menunjukkan bahwa BOPO memiliki pengaruh negatif terhadap ROA

36.

Jurnal Manajemen \& Bisnis Kreatif 
serta signifikan, karena nilai signifikansinya lebih kecil dari 0,05 yaitu sebesar 0,033. Untuk koefisien regresi sebesar -0,152 berarti setiap kenaikan BOPO sebesar $1 \%$ akan menurunkan ROA sebesar 0,152\%. Sehingga dapat disimpulkan bahwa efisiensi operasi (BOPO)berpengaruh negatif dan signifikan terhadap Return on Asset.

\subsection{Pengaruh secara parsial LDR terhadap ROA}

Hipotesis pengaruh LDR terhadap ROA menyatakan bahwa loan to deposit ratio (LDR) berpengaruh positif terhadap return on asset (ROA). Dari hasil penelitian diperoleh nilai signifikansi sebesar 0,025, sedangkan koefisien regresinya sebesar 0,032. Hal ini menunjukkan bahwa LDR memiliki pengaruh positif terhadap ROA serta signifikan, karena nilai signifikansinya lebih kecil dari 0,05 yaitu sebesar 0,025. Untuk koefisien regresi sebesar 0,032 berarti setiap penambahan LDR sebesar $1 \%$ akan meningkatkan ROA sebesar 0,032\%. Dengan demikian hipotesis pengaruh LDR terhadap ROA yang menyatakan bahwa loan to deposit ratio memiliki pengaruh yang positif terhadap return on asset diterima.

\subsubsection{Koefisien Determinasi $\left(\mathbf{R}^{2}\right)$}

Koefisien determinasi $\left(\mathrm{R}^{2}\right)$ pada intinya mengukur seberapa jauh kemampuan model dalam menerangkan variasi variabel dependennya. Nilai $\mathrm{R}^{2}$ yang mendekati satu berarti variabel-variabel independennya memberikan hampir semua informasi yang dibutuhkan untuk memprediksi variasi variabel dependen (Ghozali, 2005). Hasil perhitungan Koefisien Determinasi penelitian ini dapat terlihat pada tabel 4.9. berikut:

Tabel 4.9

Hasil Perhitungan Koefisien Determinasi $\left(\mathrm{R}^{2}\right)$

\begin{tabular}{|l|r|r|r|c|}
\hline & & & & Model Summary \\
Model & R & R Square & Adjusted R Square & $\begin{array}{c}\text { Std. Error of the } \\
\text { Estimate }\end{array}$ \\
\hline 1 & $.963^{3}$ & .927 & .901 & 1.78961 \\
\hline
\end{tabular}
a. Predictors: (Constant), LDR, CAR, BOPO, NIM, NPL
b. Dependent Variable: ROA

Sumber : Data Sekunder yang diolah

Berdasar output SPSS tampak bahwa dari hasil perhitungan diperoleh Nilai koefisien determinasi $\left(\mathrm{R}^{2}\right)$ sebesar 0,927. Dengan kata lain hal ini menunjukkan bahwa besar 
presentase variasi ROA yang bisa dijelaskan oleh variasi dari kelima variabel bebas yaitu CAR, NPL, NIM, BOPO dan LDR, hanya sebesar 92,7\%, sedangkan sisanya sebesar 7,3\% dijelaskan oleh sebab-sebab lain diluar model.

\subsection{Uji F}

Uji statistik F pada dasarnya menunjukkan apakah semua variable independen yang dimasukkan dalam model mempunyai pengaruh secara bersama-sama terhadap variabel dependennya. Hasil perhitungan Uji F ini dapat dilihat pada Tabel 4.10 berikut

Tabel 4.10

Hasil Perhitungan Uji F

\begin{tabular}{|c|c|c|c|c|c|c|}
\hline \multicolumn{7}{|c|}{ ANOVA $^{b}$} \\
\hline \multicolumn{2}{|c|}{ Model } & Sum of Squares & df & Mean Square & $\mathrm{F}$ & Sig. \\
\hline \multirow[t]{3}{*}{1} & Regression & 567.580 & 5 & 113.516 & 35.444 & $.000^{\mathrm{a}}$ \\
\hline & Residual & 44.838 & 14 & 3.203 & & \\
\hline & Total & 612.418 & 19 & & & \\
\hline
\end{tabular}

a. Predictors: (Constant), LDR, CAR, BOPO, NIM, NPL

b. Dependent Variable: ROA

Sumber : Data Sekunder yang diolah

Dari hasil analisis regresi dapat diketahui pula bahwa secara bersama-sama variabel independen memiliki pengaruh yang signifikan terhadap variabel dependen. Hal ini dapat dibuktikan dari nilai $\mathrm{F}$ hitung sebesar 35,444 dengan probabilitas 0,00. Karena probabilitas jauh lebih kecil dari 0,05 atau 5\%, maka model regresi dapat digunakan untuk memprediksi ROA atau dapat dikatakan bahwa CAR, NPL, NIM, BOPO dan LDR secara bersama-sama berpengaruh terhadap ROA.

\subsubsection{Pembahasan}

Berdasarkan hasil perhitungan analisis regresi, maka terlihat bahwa nilai coefficients untuk masing-masing variabel yang memiliki pengaruh paling besar dan signifikan terhadap Return On Asset (ROA) perbankan adalah Net Interest Margin (NIM) dengan nilai koefisien regresi sebesar 0,486; Capital Adequacy Ratio (CAR) dengan nilai koefisien regresi sebesar 0,228; kemudian Loan to Deposit Ratio (LDR)

38. 
dengan nilai koefisien regresi sebesar 0,032 ; serta $\mathrm{BOPO}$ dengan nilai koefisien regresi sebesar -0,152, kemudian Non Performing Loan (NPL) dengan nilai koefisien regresi sebesar $-0,675$.

\subsubsection{Pembahasan secara parsial pengaruh CAR, NPL, NIM, BOPO dan LDR terhadap ROA adalah sebagai berikut :}

1. Variabel Capital Adequacy Ratio (CAR)

Berdasarkan hasil penelitian Capital Adequacy Ratio (CAR) secara parsial mempunyai pengaruh positif tetapi tidak signifikan sebesar 0,228 terhadap ROA, Hal ini berarti kemampuan permodalan bank dalam menjaga kemungkinan timbulnya risiko kerugian kegiatan usahanya berpengaruh terhadap tingkat pendapatan atau "earning" yang dihasilkan oleh bank tersebut, yang pada akhirnya akan mempengaruhi pengembalian asset bank tersebut.

2. Variabel non performing loan (NPL)

Berdasarkan hasil penelitian non performing loan (NPL) berpengaruh negative sebesar -0,675 tidak signifikan terhadap ROA Hal ini berarti Apabila dilihat dari rata rata NPL pada data sekunder yang diolah diketahui rata rata NPL sebesar 5\% dapat disimpulkan bahwa PT BPR Polin Jaya sangat berhati-hati dalam penyaluran kredit kepada debitur sehingga dapat meminimalisir kredit yang diberikan menjadi bermasalah, walaupun LDR pada PT BPR Polin Jaya cukup tinggi yaitu di atas $80 \%$. Kondisi ini menyebabkan fungsi intermediasi yang diemban oleh bank menjadi optimal. Hal inilah yang diduga menjadi penyebab mengapa pada penelitian ini non performing loan (NPL) tidak berpengaruh signifikan terhadap return on asset (ROA).

3. Variabel net interest margin (NIM)

Berdasarkan hasil penelitian net interest margin (NIM) berpengaruh positif sebesar 0,486 dan signifikan terhadap ROA. Hal ini berarti kemampuan manajemen bank dalam menghasilkan bunga bersih berpengaruh terhadap tingkat pendapatan bank akan total assetnya. Bunga bersih merupakan salah satu komponen pembentuk laba (pendapatan), karena laba merupakan komponen pembentuk return on asset, maka secara tidak langsung jika pendapatan bunga bersih meningkat maka laba yang dihasilkan bank juga meningkat.

4. Variabel Biaya Operasi Pendapatan Operasi (BOPO)

39.

Jurnal Manajemen \& Bisnis Kreatif 
Berdasarkan hasil penelitian Biaya Operasi Pendapatan Operasi (BOPO) berpengaruh negative sebesar $-0,152$ dan signifikan terhadap ROA. Hal ini berarti tingkat efisiensi bank dalam menjalankan operasinya, berpengaruh terhadap tingkat pendapatan atau "earning" yang dihasilkan oleh bank tersebut. Jika kegiatan operasional dilakukan dengan efisien (dalam hal ini nilai rasio BOPO rendah) maka pendapatan yang dihasilkan bank tersebut akan naik.

\section{Variabel Loan to Deposit Ratio (LDR)}

Berdasarkan hasil penelitian Loan to Deposit Ratio (LDR) berpengaruh positif sebesar 0,032 dan signifikan terhadap ROA. Hal ini berarti kemampuan bank dalam menyalurkan kredit dari pihak ketiga kepada pihak kreditur berpengaruh terhadap tingkat pendapatan atau laba bank tersebut. Jika presentase penyaluran kredit terhadap dana pihak ketiga berada antara $80 \%-110 \%$, maka bank tersebut dapat dikatakan mempunyai tingkat likuiditas yang baik.

\subsubsection{Pembahasan secara simultan pengaruh CAR, NPL, NIM, BOPO dan LDR terhadap ROA}

Berdasarkan penelitian diketahui Nilai koefisien determinasi $\left(\mathrm{R}^{2}\right)$ sebesar 0,927 . Dengan kata lain hal ini menunjukkan bahwa besar presentase variasi ROA yang bisa dijelaskan oleh variasi dari kelima variabel bebas yaitu CAR, NPL, NIM, BOPO dan LDR, hanya sebesar 92,7\%, sedangkan sisanya sebesar 7,3\% dijelaskan oleh sebab-sebab lain diluar model. Hal ini berarti kelima variabel bebas yaitu CAR, NPL, NIM, BOPO dan LDR secara bersama sama atau simultan berpengaruh terhadap ROA sebesar 92,7\% sedangkan sisanya sebesar 7,3\% disebabkan oleh sebab sebab lainnya. Atas sebab sebab lainnya bisa ditinjau dari manajemen, sumber daya manusia dan faktor eksternal.

\section{DAFTAR PUSTAKA}

Agus Suyono. 2005. Analisis Rasio-rasio Bank Yang Berpengaruh Terhadap ROA. Tesis Program Pasca Sarjana Magister Manajemen Universitas Diponegoro (tidak dipublikasikan).

Astuti Yuli Setyani. 2002. Analisis Kinerja Perusahaan Perbankan Sebelum dan Sesudah Menjadi Perusahaan Publik Di Bursa Efek Jakarta (BEJ). Tesis Program Pasca Sarjana Magister Akuntansi Universitas Diponegoro (tidak dipublikasikan).

40. 
Bahtiar Usman. 2003. Analisis Rasio Keuangan Dalam Memprediksi Perubahan Laba Pada Bank-bank di Indonesia. Media Riset Bisnis dan Manajemen. Vol.3. No.1. April 2003. pp.59-74.

Basran Desfian. 2005. Analisis Faktor-faktor Yang Berpengaruh Terhadap Kinerja Bank Umum Di Indonesia Tahun 2001-2003. Tesis Program Pasca Sarjana Magister ManajemenUniversitas Diponegoro (tidak dipublikasikan).

Brigham, E.F dan Joel F.H,2001, Manajemen Keuangan, Jakarta: Erlangga.

Danim, Sudarwan dan Yunan Danim.2010 Administrasi sekolah dan Manajemen Kelas, Bandung : CV Pustaka Setia

Etty M. Nasser. 2003. Perbandingan Kinerja Bank Pemerintah dan Bank Swasta Dengan Rasio CAMEL Serta Pengaruhnya Terhadap Harga Saham. Media Riset Akuntansi,Auditing dan Informasi. Vol.3. No.3. Desember 2003: 217-236.

Griffin, Ricky W, 2004. Manajemen, alih bahasa Gina Gania, Edisi ketujuh, Jakarta: Erlangga

Hunger, J. David \& Thomas. L. Wheelen. 2002. Manajemen Strategis. Edisi 2. Andi. Yogyakarta.

Imam Ghozali. 2005. Aplikasi Analisis Multivariate Dengan Program SPSS. edisi 3. Badan Penerbit Universitas Diponegoro. Semarang.

Indira Januarti. 2002. Variabel Proksi CAMEL dan Karakteristik Bank Lainnya Untuk Memprediksi Kebangkrutan Bank di Indonesia. Jurnal Bisnis Strategi. Vol.10. Desember. Hal 1-26.

Jumingan. 2003. Analisis Rasio Keuangan Dan Legal Lending Limit Sebagai Alat Dalam Memprediksi Kesehatan Bank. Tesis Program Pasca Sarjana Magister Akuntansi Universitas Diponegoro (tidak dipublikasikan).

Lontoh, F \& Lindrawati. 2004. Manajemen Laba Dalam Perspesi Etis Akuntan Di Jawa Timur. Jurnal Widya Manajemen \& Akuntansi Volume 4 No.1 April. Surabaya : FE Universitas Katolik Widya Mandala.

Mucharor Djalil. 2006. Rating 131 Bank. InfoBank. No.327. Edisi Juni 2006.

Mulyo Budi Setiawan. 2004. Arsitektur Perbankan Indonesia Sebagai Upaya Memperkokoh Fundamental Perbankan Nasional. FOKUS Ekonomi. Vol.3. No.1. April 2004. Hal 38-51.

41. 
Nasser, Etty M dan Titik Aryati. 2000. "Model Analisis CAMEL Untuk Memprediksi Financial Distress Pada Sektor Perbankan Yang Go Publik.”. JAAI. Vol.4. No.2.

Pandu Mahardian, 2008. Analisis Pengaruh Rasio CAR, BOPO, NPL, NIM dan LDR terhadap Kinerja Keungan Perbankan (Studi Kasus Perusahaan perbankan yang tercatat di BEJ Periode Juni 2002 - Juni 2007) TESIS Program Pascasarjana Magister Manajemen UNDIP

Ponttie Pranasnugraha, 2007, Analisis Ratio - rasio Keuangan terhadap Kinerja Bank Umum di Indonesia (Studi Empiris Bank bank Umum yang beroperasi di Indonesia), TESIS Program Pascasarjana Magister Manajemen UNDIP

Sugiyono. 2010. Metode Penelitian Kuantitatif Kualitattif dan R\&D. Alfabeta. Bandung.

Siagian P, Sondang.2005. Fungsi - Fungsi Manajerial, Jakarta: Bumi Aksara

Singgih Santoso. 2015. SPSS (Statistical Product and Service Solutions). Elex Komputindo-Kelompok Gramedia. Jakarta

Sutrisno. 2009. Manajemen Keuangan. Pustaka Bandung

Totok Budisantoso \& Sigit Triandaru. 2006. Bank dan Lembaga Keuangan Lain. Edisi 2. Salemba Empat. Jakarta.

Wisnu Mawardi. 2005. Analisis Faktor-faktor Yang Mempengaruhi Kinerja Keuangan Bank Umum di Indonesia (Studi Kasus Pada Bank Umum Dengan Total Assets Kurang Dari 1 Triliun). Jurnal Bisnis Dan Strategi. Vol.14. No.1. Juli 2005.

Werdaningtyas, Hesti 2002, Faktor Yang Mempengaruhi Profitabilitas Bank Take Over Pramerger di Indonesia, Jurnal Manajemen Indonesia, Vol. 1, No. 2.

Z. Dunil. 2005. Bank Auditing Risk-Based Audit Dalam Pemeriksaan Perkreditan Bank Umum. PT. Indeks Kelompok Gramedia. Jakarta

Peraturan Otoritas Jasa Keuangan Nomor 20/POJK.03/2014 tanggal 19 Nopember 2014 tentang Bank Perkreditan Rakyat.

Peraturan Bank Indonesia Nomor 8/18/PBI/2006 tanggal 5 Oktober 2006 tentang Kewajiban Penyediaan Modal Minimum

Peraturan Bank Indonesia No.6/10/PBI/2004 tanggal 12 April 2004 tentang kesehatan bank 
Peraturan Bank Indonesia nomor 7/2/PBI/2005 tentang Penilaian Kualitas Aktiva Bank Umum

Peraturan Bank Indonesia Nomor: 15/3/PBI/2013 Tentang Transparansi Kondisi Keuangan Bank Perkreditan Rakyat

Surat Edaran Bank Indonesia Nomor 12/11/DPNP tanggal 31 Maret 2010

Website

www.bi.go.id

www.lps.co.id

www.okezone

43. 